\title{
小児医療におけるターミナルケアー 水田祥代
}

\section{はじめに}

小児における死のパターンには4 通りの経過 がある(1)。すなわち、1）急速に死をむかえる 場合：事故やインフルエンザ脳症などの急性疾 患、2）発症後、死まで右肩下がりの経過を取る 場合：春髄性筋萎縮症 1 型、神経変性疾患、複 雑な先天奇形など現在の医学・医療では治療不 可能な疾患、3）発達という小児の特徴のため に、発症後も状態は改善するが、ある時点をピ 一クとして次第に進行して死に至る場合：重症 の筋ジストロフィー、4）改善と悪化を繰り返す 経過をとる場合：小児がんなどで治療に反応は するが、寛解と再燃を繰り返し死にいたる疾患 等であり、いずれの場合もターミナルケアーを 必要とするが、本稿では小児がん患児のターミ ナルケアーについて述べる。

\section{1. 小児期のがんの特徵}

我が国では小児期（0１4歳）までの年間死亡 数は 1950 年には 25 万人であったが、2000年には 約 6000 人となり、2005年には約 5500 人と減り つづけている。その死因は大部分が不慮の事故 死であるが、1歳を過ぎるとがんによる死亡順位 が高くなる。

小児期のがんは大きく二つの群に分けられる。 すなわち小児がん全体の約 $40 \%$ を占める白血病
を代表とする造血器のがんと、固まりとして発 生する固形腫瘍群（約 $30 \%$ ) である。小児期の がんは多くの点で成人の場合と異なる。造血器 系のがんのうち約60\%は急性リンパ性白血病で あり、次いで悪性リンパ腫や急性骨髄性白血病 である。また、固形腫痬群もそのほとんどが非 上皮性であり、神経芽腫や肝芽腫、腎芽腫など であり、成人にみられるような胃がんや肺がん などの腺がんや上皮性がんは極めてまれである。 年齢によって好発する腫瘍が異なり、神経芽腫、 網膜芽腫や肝芽腫などは大部分が乳幼児期に発 生し、急性リンパ性白血病はリンパ組織の発育 増殖が著しい幼児期に多く、骨腫瘍 (骨肉腫、 ユーイング肉腫）は骨の発育増殖の著しい思春 期に多い。また、成人のがんと比べて抗ガン剂 や放射線療法に対する感受性が高いという特徴 を持っている。

筆者が医師になった1960年代後半当時、小児 がん、特に小児外科で扱う固形腫瘍は手術もで きないような重症な症例が多く、まさに不治の 病であったが、40年を経た今日、早期診断の普 及や数々の新しい治療法の開発によって治療成 績はめざましく向上し、今や小児がんの70\%は 治癒を望みうる時代となっている。しかし、ど んなに最善を尽くしても、小児がんの中の $30 \%$ は死から逃れることのできない子ども達がいる ことも現実であり、希望に満ちた未来が断ち切 られる患児自身はもとより、見送る両親や家族 
の思いにそったターミナルケアーが必要となる。

\section{2. 小児期のターミナルケアーの実際}

小児がんの治療は医師、看護師、心理士、保 育士、ケースワーカーなどによるチーム医療が 重要であり、このスタッフ間のコミュニケーシ ヨンを密に取ることが大切である。特に小児が んのターミナル期には、患児の身体的苦痛を軽 減させる治療のみならず、患児の年齢・発達に 応じて病状や病名を伝えたり、また患児の両親 や兄弟を含めた家族へのサポート等の精神的要 素も医療チームに求められる大きな割合を占め るようになる。

\section{1）ターミナルケアーの開始}

一般的にターミナルケアーは医療者がもう治 㾍は望めないと考光、患者さんや家族に緩和ケ アーをオプションの一つとして提示し、それが 受け入れられた時点で始まるが、実際には受け 入れられるまでにはかなりの時間差があるのが 普通である。特に小児がんの場合は抗ガン郕な どへの感受性が高いために、治癒への期待度が 大きく、医療側も含めてターミナルへの心構え が遅れる場合が多い。望ましいのは診断当初よ り患児の病状によってターミナルケアーも対象 に入れておくことである。すなわち診断当初は 治㾍を目標とした治療を行いながら、検査や治

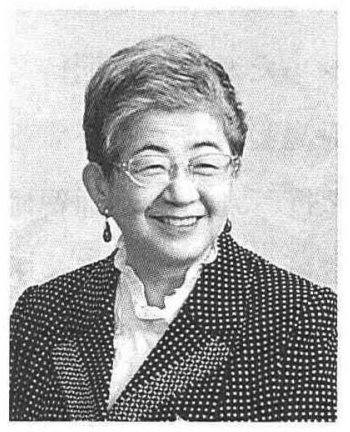

\section{PROFILE}

水田祥代

(すいた さちよ 1942年生)

日本学術会議第二部会員、九州

大学教授、九州大学病院長

専門：臨床医学、小児外科学
療に伴う苦痛の軽減や、精神的負担などを軽減 するようなサポートを行い、治癒が望めないこ とが判明した時点で緩和ケアーを主体としたタ 一ミナルケアーへと移行してゆくやり方である。

\section{2）誰がターミナルケアーを決めるのか：}

\section{患児・両親とのコミュニケーションの}

\section{重要性}

小児、とくに乳幼児期のターミナルケアーで は両親の意向によって治療方針が決定されると いう特徴がある。治る見込みが無くなった場合 には「苦痛を伴う治療はせずに、子どもの好き なことをさせる」あるいは「最期はできるだけ 苦痛が無く静かに過ごさせたい」と思う両親や、 あるいは「最期まであきらめずに治療を続けさ せたい」と望む両親があり、親の価值観によっ て意思決定は大きく影響される。さらに、父親 と母親の間でも意思の相違があることも多く、 また若い両親の場合には祖父母の価值観によっ ても影響される。さらに一度決めたことも日に 
よって変わることも多い。

筆者は次の様な場合を経験している：患児は 7歳男児。進行がんで術後転移を認め、強力な集 学的化学療法を行ったが治癒は期待できない状 態となった。ご両親と何度もあらゆる可能性に ついて話し合いを行った後、ご両親はこれ以上 のつらい治療を受けるのは止めて、子どもに思 い出を作ってやりたいと家族でハワイ旅行する ことを希望された。旅行の危険性などを説明し た上で、ハワイでの救急時の受け入れ先の病院 の手配を行った。時々電話での相談にのり、2カ 月後に帰国したが、間もなく呼吸困難で当院に 入院し、7日目に亡くなった。本人は飛行機に乗 ったことやハワイの海で泳いだ事などをとても 楽しかったと話し、また父親も思い出をつくっ てやれたと大変満足していた。しかし、母親は 最後に「ハワイなど行かずに化学療法を続けて いればまだ生きていたかもしれない。自分は最 後まで治療を続けさせたかった」といわれた。

この場合患児自身はどう思っていたのかに関 しては、当時筆者らは中学生になっていない患 児への病名告知や、病状説明は行っていなかっ たため不明であるが、本当にそれで良かったの だろうか？医療に扎ける生命倫理は従来から、 古代ギリシャ時代の「ヒポクラテスの誓い」が尊 重され、いわゆるpaternalism (家長主義)のも とに患者のためになることだからと患者に説明 せずに医師の判断で決められてきた。しかし近 年、患者のautonomyを尊重する考えのもとに、 「身体・生命についての最終判断を行う権利は、 成人では正常な判断能力を持っている限り患者
自身に存在する」とする患者の自己決定権の考 え方は我が国でも定着してきており、法的に法 定代理人が付される20歳未満であっても、医療 に関しては医療行為について理解、判断能力が あると認められれば患者本人の承諾でたりうる と考えられている ${ }^{(2)}$ 。

小児医療の場合、特に年少児の場合、患児が この意志決定能力、autonomyを持っていない こと等の問題がある。したがって、基本的には 親権者 (父母) あるいは後見人などの法定代理人 の承諾を得て医療行為をすることとなる。

我が国では成人の場合でもがんについての本 人への告知は未だに行わない場合があり、小児 の場合は、1993年に金子ら ${ }^{(3)}$ の小児がん医療 に従事している医師を対象としたアンケート調 査によると、回答のあった 372 人中患児に本当 の病名を告知したことのある医師は 132 人 (35.6\%) であり、そのうち重症、予後不良でも 知らせると回答した医師は $10 \%$ ありり、両親を 説得して知らせたのが $13.6 \%$ あっあた。また 告知経験のない医師 239 人中「告知を必要と思 う」医師は 144 人、 $60.2 \%$ であり、この 144 人が 告知していない理由は、「知らせた後のフォロー (患者ケアー) に不安がある」「両親が知らせる事 に反詨する」「患児の年齢が低かったので理解で きない」ことを挙げている。告知の必要が無い と答えた医師はその理由として「子どもだから 理解できない」：47.9\%、「精神的ショックを受

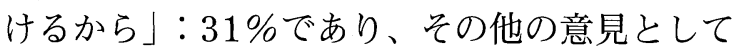
「希望のある状態にしておきたい」、「成人と異な り身辺整理をする必要がない」、両親に十分し 
らせてあるから」などを挙げている。また、告 知の年齢については $31.1 \%$ が8歳以上、 $28.8 \%$ が 15歳以上と回答し、その他として10歳以上や治 癒例が成人になったときという回答であった。

米国では以前から小児がんの子ども達全員に病 名を伝え治療を行う方針が取られており、小児の IC (informed consent)については新生児〜幼児 期には両親が代理で決定すること、7～14歳にお いては医療行為への小児自身の賛意が必要である とするIA (Informed assent) の概念が述べられ ている ${ }^{(4)}$ 。また、国際小児がん会議 (SIOP) で は末期の小児がん患児をサポートするためのガイ ドラインが作成され、その中に年齢に応じた病名 告知の必要性が述べられている ${ }^{(5)}$ 。

従って、我が国に扎いても最近は子どもを一概 に理解力や同意能力がないものと捉えるのではな く、患児のdeveloping autonomyにそって病名 や病状を告知する場合が多くなっている ${ }^{(6,7)}$ 。

このような病名告知は治療においてもその効 果は大きいと考えられている。医療者が子ども に何の説明もせずに、押さえつけて痛みを伴う 治療を行うことは医療の名を借りた虐待であり、 患児には精神的トラウマとなる危険性が大きい。 患児は自分のことは知りたいのである。従って 診断時に両親のみではなく、患児に対しても病 気の説明や検査の必要性、治療期間やそれに伴 う副作用などについて患児の年齢や理解度に応 じて行うことは大切であり、医療人が嘘をつか ないことを示し、両者の間にオープン・コミュ ニケーションの確立ができ、さらに子ども自身 の意見や希望をきき、それに応じたspiritual supportも可能となる。

ではいくつから子どもは死を理解するのであ ろうか？ 藤井は健康な子どもの死の概念（身 体の機能停止 · 非可逆性 - 普遍性など) の発達 を考えると、0〜2歳では死を「みえない(イナ イ、イナイ、バー)」または動かないと思ってお り、3〜5歳では死を「一時的な別離」や「睡眠」 と考元、別の世界 (天国、星)へ行くなど別の存 在 (天使。幽霊)になったり、「生き返る」と考 え、6〜11歳では死の非可逆性 (生き返れないこ と）を理解するが、自分自身は死を回避できる ものと考える。12１8歳で、死の普遍性 (人は 誰でも、いつかは死ぬ事) を理解し、死後に関し ては魂・霊になる、生まれ変わる、すべて終わ りと 3 通りの考え方をしめすと報告している ${ }^{(7)}$ 。 また、重篤な疾患の子どもは、同じ年齢の子ど もより年少で死を意識する場合が多く、米国で は4歳を越えると死を自覚し、5〜6歳以上では ターミナル期には周りの大人が秘密にしていて も自分に死が近づいていることを悟り、恐れを 感じ、死への不安を言葉で表現すると報告され ている ${ }^{(8)}$ 。我が国でも細谷らの調査によると、 4歳未満では死への恐怖を直接言葉にはできない が、号泣などの行動化で察することができ、4〜 11歳では70\%が、11歳以上では全例が死への恐 怖を表現していたという両親のアンケート結果 を報告している ${ }^{(9)}$ 。

\section{3）身体的症状への対応：特に苦痛の軽 減・除去}

小児においてもがんによる痛みは成人の場合 
と同じように存在する。しかし、小児にとって は、がん自体の痛みよりもむしろ処置、検査や 治療による痛みの方が重大な問題となる場合が 多い。採血や化学療法のための静脈ラインの確 保、骨髄穿刺などが十分な説明もなく押さえつ けられて行われることは、患児にとって恐怖で あり、まさに虐待である。

小児の場合も痛みの発生メカニズムは成人と 何ら異なることはないが、小児の場合、痛みの 程度や性質を的確に表現できないために、痛み の評価がむつかしい。しかし、最近はフェイス ペインスケールなどが開発され、子どもの痛み に対する評価の補助となっている。

治療としては、1998年にWHO（世界保健機 関) が発表した小児がん疼痛治療指針によると 小児における鎮痛のための薬物療法は最も簡単 な方法で、最も効果的で、最も痛みの少ない経 路から投与されるべきであることで、経口投与 を基本とするとしている ${ }^{(10)}$ 。最近では小児に対 してもオピオイドの利用が理解されるようにな り、PCA (Patient Controlled Analgesia) の活用が広まっている。また、フェンタニール パッチ (デユロテップパッチ) は皮膚に貼るだけ でモルヒネ持続静脈投与に匹敵する効果が得ら れるため、利点は大きい。さらに、モルヒネ静 脈内投与同様の即効性を持つ経口腔粘膜フェン タニル製片(フェンタニルキャンディ）も米国で は認可されており、より非侵襲的な鎮痛剤投与 が可能となっている。

小児の疼痛に対しては薬物療法のほかに、医 療者が患児や家族と信頼関係を築くことにより、
理学療法や心理療法などの集学的、全身的ケア 一も効果を示す。

\section{4）ターミナルケアーを行う場所}

欧米ではターミナルケアー専門の病院があり、 専門の資格を持つナースや支援するボランティ ア等がそろっているし、また在宅での支援をす るスペシャリストナースも存在する。筆者が留 学していた英国の小児病院では 1960 年代後半 に、すでに家族用の部屋や建物があり、患児は 家族と一緒に過ごしながら緩和医療を受け、タ ーミナルへと入っていった。しかし、我が国で はそのような体制はまだ不十分で、病院におい てさえもターミナルケアーを十分に行える設備 のみならず、重症な患児を家族ぐるみで支える ことのできる設備はまだ大変少ない。最近やっ と病棟の中にファミリールームの設置や病院の 敷地内にマクドナルドハウスが設置されてきて いる。

筆者はターミナルを迎えた患児に接するたび に英国での経験を思い出し、何とかならないか と思っていたが、ある時進行がんで再発を繰り 返し、集学的化学療法にも反応しない 4 歳女児の 担当となった。とても明るい子で病状がひどく なっても意識は清明で異常な食欲があり、私が 病室へ行く度に「○○をたべていい？」と食べた いものを羅列し、よく三つ違いのおねーちゃん の話をしてくれた。病室へは中学生未満は入れ ない規則であったが、ご両親もおねーちゃんに あわせてやりたいと希望したので、おねーちゃ んをこっそり病室に入れて最後の 2 日間を親子 4 
人で過ごしてもらった。幸い当時の小児外科の 病棟は建物の端っこにあり、裏には非常階段が あったので、おねーちゃんにはそこから出入り してもらった(後で私は関係者から叱られたが、 患児は満足し、ご両親やおねーちゃんはとても 喜んでくれた)。ターミナルケアーにおいては患 児やその家族がいかに気持ちよく最後の時を過 ごせるかがポイントであり、病院の中にターミ ナルケアーを十分に行える場所がない場合には、 せめて病院の規則を緩和できるようにするべき であると思う。

\section{5）家族へのケアー}

本来ならば病気や死からもっとも縁遠いはず の子ども達が病気であることや、両親より先に 逝くということは、両親はもちろん、その子ど もと共に過ごしてきた人たちにとっては非常に 耐え難いことであり、このような場合における ターミナルケアーに際しては成人の場合以上に その家族への配慮が必要とされる。多くの場合 母親が病院での看護につき、父親が残された兄 弟姉妹の面倒を見るが、病院での看護に疲れた 母親のサポートと同時に仕事をしながら留守を 預かる父親や、両親の関心が病気の兄弟姉妹に 集中することで、疎外感を感じやすくなってい る兄弟姉妹達への配慮も大切である。

また、患児の死後、両親や家族の立ち直りを サポートするgrief careも重要である。欧米で は教会などからの宗教的サポート等もあるが、 我が国では「がんの子どもを守る会」や病院での プライベートな患者遺族会などの活動に支えら
れているのみであり、十分とは言えない。また、 医療人の多くは気になりながらもどのように対 応して良いのか分からないのも事実であろう。

親にとって子どもを亡くした悲しみは一生続 く悲しみであるが、悲しんでいるだけではなく、 子どもをしくした後もその子との関係を再構成 して自分の中に位置づける事で立ち直ろうと努 力している ${ }^{(11)}$ 。筆者はがんでお子さんを亡く されたお母様から病棟を訪ねたいと言われたと き、病棟で亡くなられたお子さんを思いだして つらいのではないかと心配したが、「ここへくる と、みんながKちゃんのおかーさん！って呼ん でくれるので、あの子が元気でいるようで嬉し いのです」と言われたことがある。

\section{終わりに}

我が国では成人のがん領域において1970年代 から終末期で死にゆく過程にある患者さんへの ケアーが注目を浴び、ホスピスや緩和ケアーを 提供するシステムが整備されつつある。しかし、 小児がんの領域では、これらの問題についての 研究や検討はまだ少なく、残された課題は多い。

筆者は約40年間小児外科医として小児医療に 携わってきた。ピーピー泣いていた赤ちゃんが いつの間にか小学生になり、鉛筆書きの手紙が 来たりするとついニターとなってしまう。そし てまた、街の中で「先生！」と声をかけられる と、傷の処置や注射のたびに悪態をつかれてい たことなどすっかり忘れ、それだけで一日が八 ッピーになる。しかしまた、元気になった子ど 
もよりも、全力を尽くしてもなお救うことの出 来なかった子どものほうがいつまでも心に残っ ているのは、医師である人すべてがもっている 気持ちであろう。一つの命が消えるたびにどう しようもなく気分が落ち込むが、その落ち込み から自分自身が立ち直るに要する時間が1月か ら、2週間、1週間、5日、3日と年齢を重ねる毎 に短くなって行くことに何かしらうしろめたさ を感し、そしてさらに落ち込むという悪循環を 繰り返してきた。

今朝も 生きていた

わたしの 子供が生きていた

今朝も 生きていた

今日も 生きていた

今朝も 生きている

ありがとう

これは小児がんのお子さんを持つあるお母様 からいただいた手紙である。この気持ちに報い たい、そして報われたい。
文献

1. 日本医師会 第1X時生命倫理懇談会：「ふたたび終末期 医療について」の報告、2006

2. 加藤済仁、多胡博雄 : 小児医療におけるインフォームド コンセントーその法的側面、小児内科26（4）：513517, 1994

3. 金子安比古、松下竹次：小児がん医療における病名告知、 インフォームドコンセント、サポーティブヶアーの現状、 日本小児科学会雑誌、99（2）：534-539，1995

4. The National Commission for the Protection of Human Subjects of pBiomedical and Behavioral Research (Belmont Report 1979)

5. Spinetta,JJ etal:Valid Informed Consent and Participative Decision-Making in Children With Cancer and Their Parents:A Report of the SIOP Working Committee on Psychosocial Issues in Pediatric Oncology, Med Pediatr Oncol 40:244246,2003

6. 恒松由紀子; 小児への情報伝達とケア、緩和医療学5 (4) : 346-356, 2003

7. 藤井祐治 : 死を余儀なくされる子どもへの対応、小児看 護27（9）：1057-1062，2004

8. Bluebond-Lanngner $M$ : Worlds of dying children and their well siblings. Death Studies 13:1-16,1989

9. 細谷亮太 ; 小児がん患者のターミナルケアーとデス・エデ ユケーション、ターミナルケアー1 : 105ー109, 1991

10. WHO: Cancer pain relief and palliative care in children. Geneva, 1998

11. Himelstein BP et al: Pediatric Palliative Care, N Engl J Med 350:1752-1762, 2004

日本学術協力財団の出版図書

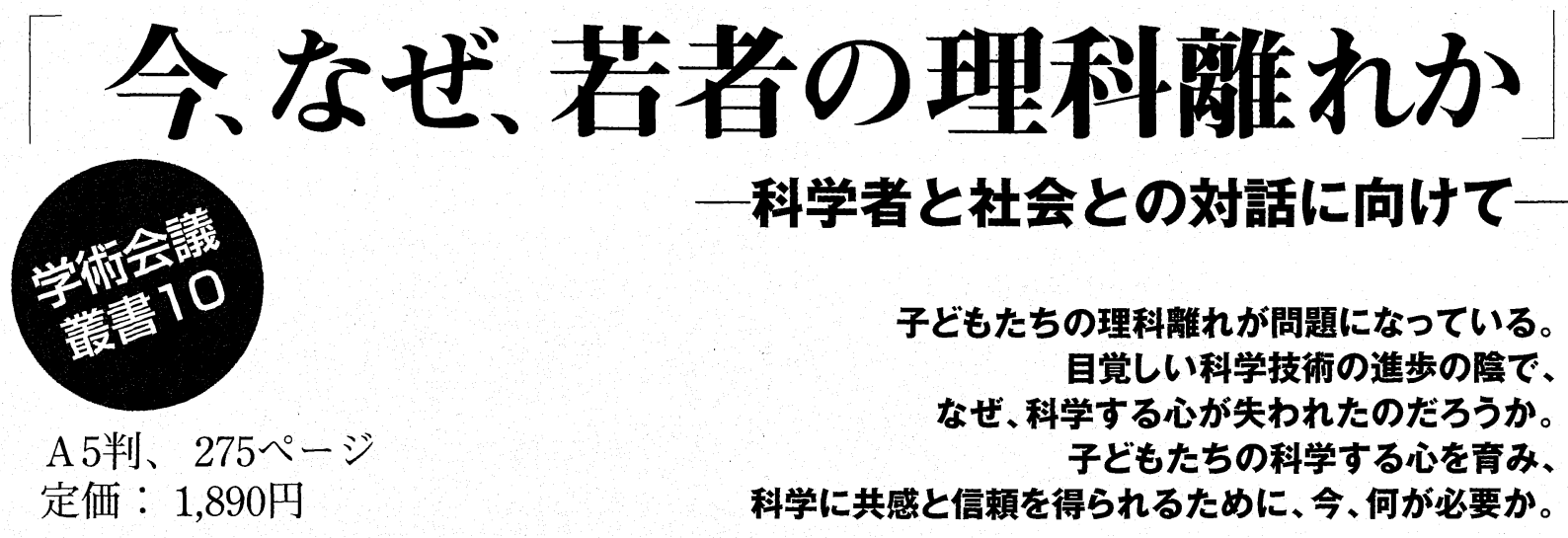

